Research Article

\title{
Quick detection of iron in contaminated water before feeding to RO membranes
}

\author{
Rajesh Kumar $^{1} \cdot$ Meenakshi Kachwaha $^{1} \cdot$ Sunita Verma ${ }^{1} \cdot$ Deepesh Patidar $^{1}$
}

(c) Springer Nature Switzerland AG 2019

\begin{abstract}
This paper describes the need for detection of iron, preparation method of colorimetric material and response studies for detection of iron in contaminated water. Iron is a membrane foulant, and high concentration of it produces membrane fouling. Membrane fouling decreases the flux rate and efficiency of salt rejection and makes the membrane more susceptible to oxidation damage. Therefore, iron detection is essential in feed water before passing through RO membrane. Under this objective, a material was prepared through reaction of 1,10-phenanthroline with ascorbic acid and trisodium citrate (weight ratio 1:1:2). The prepared material shows significant response towards iron, and it is observed through naked eye. A yellow colour to change into orange red colour was observed within 5 min when material was exposed to $\mathrm{Fe}(\mathrm{II})$ ions at $300 \mu \mathrm{g} / \mathrm{L}$ as per IS 10500 . UV-visible spectra of 1,10-phenanthroline-Fe complex show absorbance at wavelength $510 \mathrm{~nm}$ with iron without interference of other metal ions, viz. $\mathrm{Cd}(\mathrm{II}), \mathrm{Co}(\mathrm{II}), \mathrm{Ni}(\mathrm{II}), \mathrm{Hg}(\mathrm{II}), \mathrm{Zn}(\mathrm{II}), \mathrm{Pb}$ (II) and high TDS water.
\end{abstract}

\section{Graphical abstract}

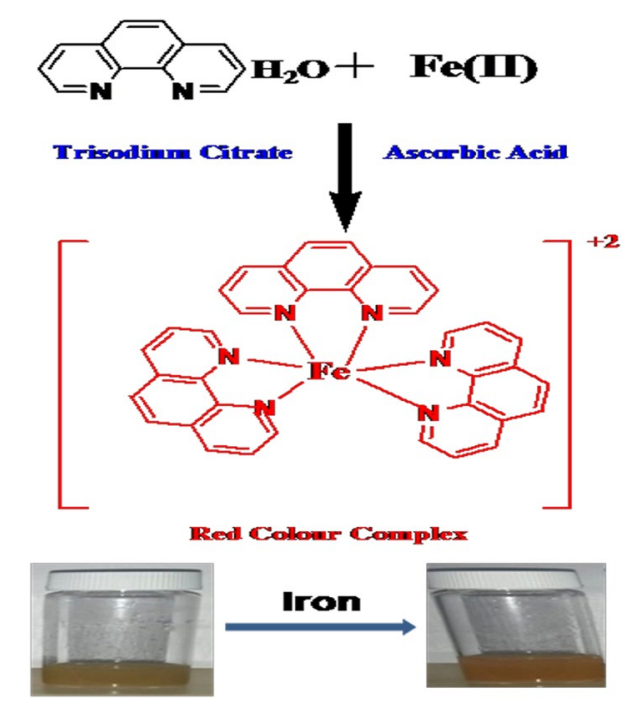

Keywords Ascorbic acid · Detection · Fouling · Iron ion · Naked eye · 1,10-Phenanthroline · RO membranes · UV-visible

Rajesh Kumar, rnunia@rediffmail.com | 'Defence Laboratory, Water Quality Management Group, Desert Environmental Science and Technology Division, Ratanada Palace, Jodhpur, Rajasthan 342011, India.

SN Applied Sciences (2019) 1:427 | https://doi.org/10.1007/s42452-019-0379-6

Received: 25 December 2018 / Accepted: 18 March 2019 / Published online: 8 April 2019 


\section{Introduction}

Water is contaminated with various impurities, viz. TDS, alkalinity, hardness, chloride, fluoride, nitrate, $\mathrm{pH}$, calcium, magnesium, iron and toxic metal ions. Iron beyond permissible limit is one of the toxic metals [1]. Iron contamination in water is generally due to dissolution of ores, rusting and decomposition of water supply pipes [2].

Iron is one of the foulants present in feed waters in membrane filtration processes. Iron can be found in two forms and is influenced by a variety of variables including $\mathrm{pH}$, metal ions and ionic strength. Iron is present in water forms, viz. ferrous and ferric. The ferrous is watersoluble, and ferric is water-insoluble. Ferrous can be removed by iron filters, softeners or precipitation and treated with dispersant chemical. Ferrous iron is converted into insoluble ferric iron through oxidation by induction of air into water. Soluble iron can be found in deep wells, but gets converted into more troublesome insoluble iron by the introduction of air. Insoluble ferric iron oxides or ferric hydroxides, being colloidal in nature, will foul the front end of the RO system. Sources of insoluble iron are aerated well waters, surface sources and iron scale from unlined pipe and tanks.

RO membrane manufacturers recommend that combined iron levels be less than $0.5 \mathrm{ppm}$ in the RO feed. If all iron is in the soluble ferrous form, iron levels up to $0.5 \mathrm{ppm}$ in the feed can be tolerated if the $\mathrm{pH}$ is less than 7. The sources of iron fouling are hydroxide flocs of oxidized iron, corrosion products from piping materials and silicates containing iron [3-8]. Iron fouling increases RO feed pressure requirements, increases permeate TDS, decreases efficiency of salt rejection, decreases flux of product water and makes the membrane more susceptible to oxidation damage and bio-fouling.

Therefore, there is a requirement to detect iron in feed water before passing it through RO membranes. With this objective, colorimetric material has been prepared and response study towards iron carried out. The colorimetric material is capable of detecting 300 ppb iron in feed water within $5 \mathrm{~min}$.

The thin-film composite (TFC) reverse osmosis (RO) is sensitive to iron fouling, and manufacturer recommends iron should not be more than $0.5 \mathrm{ppm}$ in feed water. Most of the tube well water and other sites water is having iron in $\mathrm{mg} / \mathrm{L}$ (ppm) range or more than recommended limit. Therefore, a material is required to detect iron and take decision to feed contaminated water. If it is within permissible limit or to treat it before feeding when it is exceeding the limit. This exercise increases the shelf-life of membrane and gives high percentage salt rejection. This manuscript details the work carried out in this direction and its outcome. colorimetric analysis is based on the change in the intensity of the colour of a solution with variations in concentration [9-11]. colorimetric methods represent the simplest form of absorption analysis. The human eye is used to compare the colour of the sample solution with a set of standards until a match is found [12].

Various materials have been reported in the open literature, viz. 1,10-phenanthroline and 2,2', dipyridyl and thiocyanate with hydroxylamine and $\mathrm{HCl}$ are mostly used for detection of iron in field conditions [13-15]. A number of techniques have been used for detection of iron ions in water, viz. atomic absorption spectrophotometer $[16,17]$ and inductively coupled plasma mass spectrometry [18, 19]. However, these techniques have limitations, viz. they are costly, require sophisticated instruments and to be operated by skilled analyst, and are not possible to use in field. Various iron detection kits have been developed by different laboratories and companies. These are also able to analyse iron. These kits are having three liquid chemicals, viz. phenanthroline, hydroxylamine and concentrated $\mathrm{HCl}[20,21]$. Hydroxylamine and concentrated $\mathrm{HCl}$ are carcinogenic and corrosive, and safety is also required. Therefore, a colorimetric material was prepared using nontoxic and non-carcinogenic materials, viz. ascorbic acid as a mild reducing agent and trisodium citrate as a buffer for maintaining $\mathrm{pH}$. The material shows significant response towards iron at $300 \mu \mathrm{g} / \mathrm{L}$ concentration within $5 \mathrm{~min}$.

\section{Experimental}

\subsection{Instrumentation}

The $\mathrm{pH}$ measurements were made on a digital $\mathrm{pH}$ meter (HACH, sension 1, model 51935-00, Loveland, Colorado, USA) equipped with a gel-filled $\mathrm{pH}$ electrode. The meter was calibrated with the buffers of 4, 7 and 10. Absorbance spectra of material with water were recorded on UV-visible spectrophotometer Analytik Jena SpecordS600 (Germany). IR spectra were recorded on JASCO FT-IR spectrometer model JASCO- 610 by using $\mathrm{KBr}$ pellets. All solutions were prepared through serial dilution of stock solution $1000 \mathrm{mg} / \mathrm{L}$ and concentration estimated through atomic absorption spectrophotometer Analytik Jena Nova 400(Germany).

\subsection{Chemicals and solutions}

1,10-Phenanthroline monohydrated (99.5\%), ascorbic acid (99.7\%) and trisodium citrate (99\%) were purchased from Merck (Darmstadt, Germany). All metal 
ions standard solutions $1000 \mathrm{mg} / \mathrm{L}$ were purchased from Merck (Mumbai, India), and desired concentration solutions were prepared through serial dilution.

All of the reagents used were of analytical grade. All laboratory wares used for analytical determination were cleaned first by trace-metal-grade nitric acid and hydrochloric acid, followed by repeated rinsing with deionized water. All the solutions were prepared with ultrapure water (resistivity $18.2 \mathrm{M} \Omega \mathrm{cm}$ ) from an Elix analytical reagent-grade water purification system.

\subsection{Preparation of material}

1,10-Phenanthroline $(5 \mathrm{~g})$, sodium citrate $(10 \mathrm{~g})$ and ascorbic acid $(5 \mathrm{~g})$ were grinded in mortar and put into the sealed glass bottle.

\section{Results and discussion}

\subsection{Characterization of 1,10-phenanthroline and 1,10-phenanthroline complex with iron}

The FT-IR spectrum of 1,10-phenanthroline was performed (Fig. 1). The absorption bands localized at $3399 \mathrm{~cm}^{-1}$, 3077 due to $C=C$ stretching vibrations. Strong band was observed at $700-900 \mathrm{~cm}^{-1}$ and $1400-1650 \mathrm{~cm}^{-1}$. The strong bands 735 and 885 were assigned to pyridine molecule. The FT-IR spectrum of complex of iron with 1,10-phenanthroline was obtained similar to phenanthroline but strong band appeared at $714 \mathrm{~cm}^{-1}$ due to complex of Fe(II).

The colorimetric material was prepared successfully and evaluated for detection of iron by varying parameters, viz. quantity of material, the presence of other metal ions and

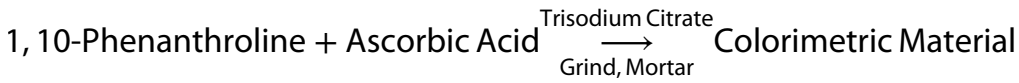

\subsection{Evaluation studies of material with Iron}

Initially, the reaction of 1,10-phenanthroline with iron was performed as a model reaction in the presence of various reducing agents and by varying reaction conditions. The efficiency of various reducing agents such as hydroxyl amine, anthraquinone, hydroquinone and ascorbic acid was studied in different mole ratios (1-2 mol\%). Ascorbic acid gave best result with trisodium citrate as buffer. Effect of buffer was also studied by using various buffers such as trisodium citrate, potassium citrate and $\mathrm{HCl}$ for acidic condition, and it was observed that sodium citrate afforded the best results.

The maximum response of 1,10-phenanthroline was obtained when the reactions were carried out using 1:1:2 weight ratio of 1,10-phenanthroline, ascorbic acid and trisodium citrate, respectively. The process involves mixing 1,10-phenanthroline, ascorbic acid and trisodium citrate in a mortar and grinding the mixture at room temperature for 10-15 min in low humidity environment. After that, the obtained product is kept in air-tight vial. The prepared material was used for detection of iron by varying quantities $0.1-1 \mathrm{~g}$. After the experiment, it was found that $0.5 \mathrm{~g}$ is sufficient for $20 \mathrm{~mL}$ contaminated water.

Take $0.5 \mathrm{~g}$ of material in glass vial and close it. Then inject $20 \mathrm{~mL}$ of iron-containing water into the vial and observe colour changes. The colour change and intensity depend on the presence of iron concentration. The wavelength of maximum absorbance intensity, $\lambda \max$, was determined using UV-visible spectrophotometer.
$\mathrm{pH}$. The colorimetric material was prepared using nontoxic and non-carcinogenic chemicals such as phenanthroline, ascorbic acid and trisodium citrate. Toxic and carcinogenic materials, viz. $\mathrm{HCl}, \mathrm{NH}_{2} \mathrm{OH}$, were used for detection of iron in the most of reported methods.

\subsection{Evaluation studies}

Take $0.5 \mathrm{~g}$ of material in vial, and inject $20 \mathrm{~mL}$ of contaminated water. Initially, the experiments were carried out with distilled water, $300 \mu \mathrm{g} / \mathrm{L}, 600 \mu \mathrm{g} / \mathrm{L}$ and $900 \mu \mathrm{g} / \mathrm{L}$ ironcontaining water. The red orange colour appeared within $5 \mathrm{~min}$ with $300 \mu \mathrm{g} / \mathrm{L}$ iron-containing water. The colour intensity of solution increased with increasing concentration of iron as shown in Fig. 2.

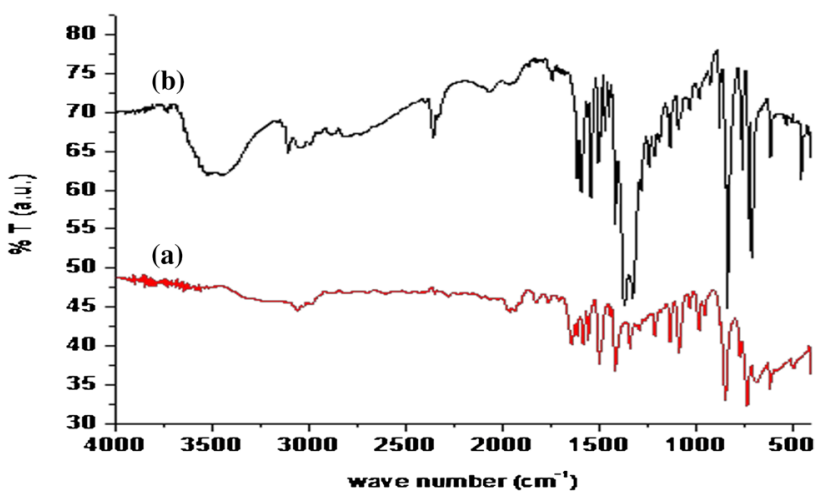

Fig. 1 FT-IR spectrum of (a) 1,10-phenanthroline (b) complex of $\mathrm{Fe}(\mathrm{II})$ with phenanthroline 
The wavelength of maximum absorbance intensity, $\lambda \max =510 \mathrm{~nm}$, was obtained as shown Fig. 2 . This large value indicates the complex absorbs very strongly. The intensity of the colour is independent of $\mathrm{pH}$ in the range $2-9$. The complex is very stable, and the colour intensity does not change within 2 days of time (Fig. 3; Scheme 1).

The colour change was due to formation of complex of 1,10-phenanthroline with iron(II). The material forms quick complex with iron (II) and is observed by naked eye. Therefore, to determine the total iron in the sample, the iron must be completely in iron (II). Ascorbic acid is used as a reducing agent which converts $\mathrm{Fe}$ (III) into $\mathrm{Fe}(\mathrm{II})$. However, material also forms a coloured complex with Fe(III) with long time and the colour is not as intense. Hence, the total iron is detected by the reaction of material with iron (II) via $\mathrm{Fe}(\mathrm{II})$-o-phenanthroline complex. The reduction of $\mathrm{Fe}$ (III) to $\mathrm{Fe}(\mathrm{II})$ is represented by the following reaction

$2 \mathrm{Fe}^{3+}+\mathrm{C}_{6} \mathrm{H}_{8} \mathrm{O}_{6} \rightarrow 2 \mathrm{Fe}^{2+}+\mathrm{C}_{6} \mathrm{H}_{6} \mathrm{O}_{6}+2 \mathrm{H}^{+}$

Advantages of ascorbic acid use as reducing agent are as follows: ascorbic acid reduces Fe(III) to Fe(II) more rapidly and is not carcinogenic. Trisodium citrate is used as a buffer for adjusting the $\mathrm{pH}$ value of reaction between 3 and 7.

\subsection{Interference ion study in the presence of different metal ions in high TDS water}

The evaluation studies were carried out for different metal ions, viz. $\mathrm{Ni}, \mathrm{Cu}, \mathrm{Co}, \mathrm{Zn}, \mathrm{Hg}, \mathrm{Pb}, \mathrm{Cd}, \mathrm{Cr}$, Fe and high TDS, separately as well as contamination of the above-said metal ions in high TDS $(6000 \mathrm{mg} / \mathrm{L})$ water. The result in Table 1 shows that the material showed no change in colour with $\mathrm{Ni}, \mathrm{Cu}, \mathrm{Co}, \mathrm{Zn}, \mathrm{Hg}, \mathrm{Pb}, \mathrm{Cd}, \mathrm{Cr}$ and high TDS separately and mixer of metal ions in high TDS water. But the material shows colour change in the presence of iron with different ions. Hence, material has no interference of other metal ions during detection of iron in contaminated water (Fig. 4).

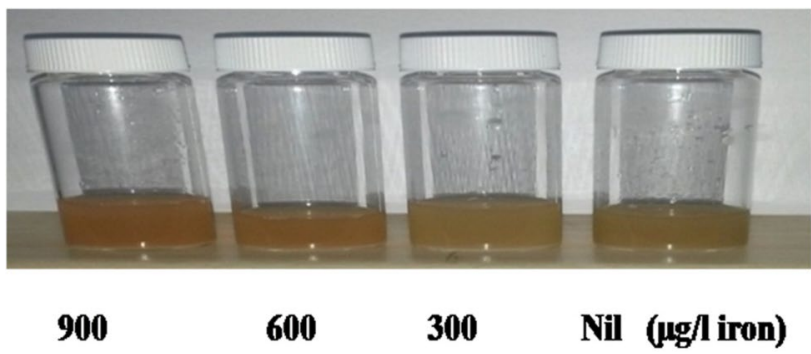

Fig. 2 Photographs of colour change of material with different concentrations of iron

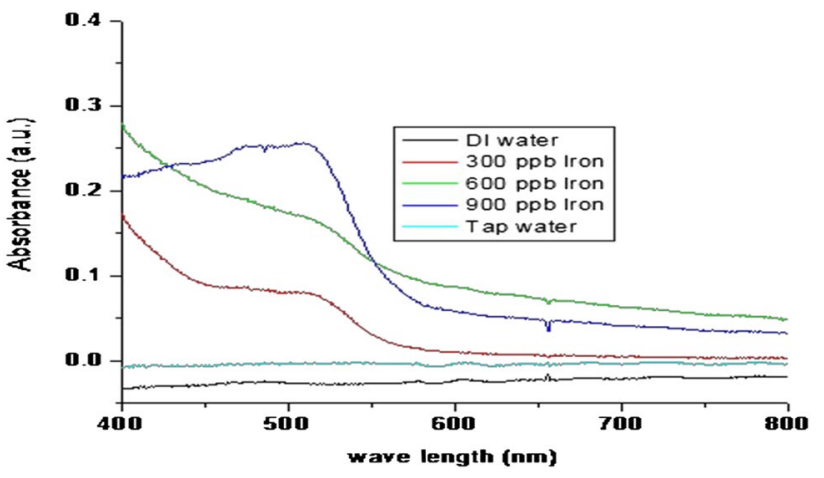

Fig. 3 UV absorbance spectra of 1,10-phenanthroline with different concentrations of iron

Absorbance studies of solutions were carried out with UV-visible spectrophotometer for maximum absorbance intensity; $\lambda \max =510 \mathrm{~nm}$ was obtained for iron $(1000,600$, $300 \mu \mathrm{g} / \mathrm{L}$ ), mixture 1 and mixture 2 and high TDS with iron. No absorbance was observed for $\mathrm{Ni}, \mathrm{Cu}, \mathrm{Co}, \mathrm{Zn}, \mathrm{Hg}, \mathrm{Pb}$, $\mathrm{Cd}, \mathrm{Cr}$ and high TDS at $300 \mu \mathrm{g} / \mathrm{L}$ concentration as shown in Fig. 5.

\subsection{Effect of $\mathrm{pH}$}

The colour change and its intensity depend on the $\mathrm{pH}$ of solution. The colour change obtained within $5 \mathrm{~min}$ in contaminated water when $\mathrm{pH}$ between 2 and 7 due to fast complex formation of 1,10-phenanthroline-Fe.
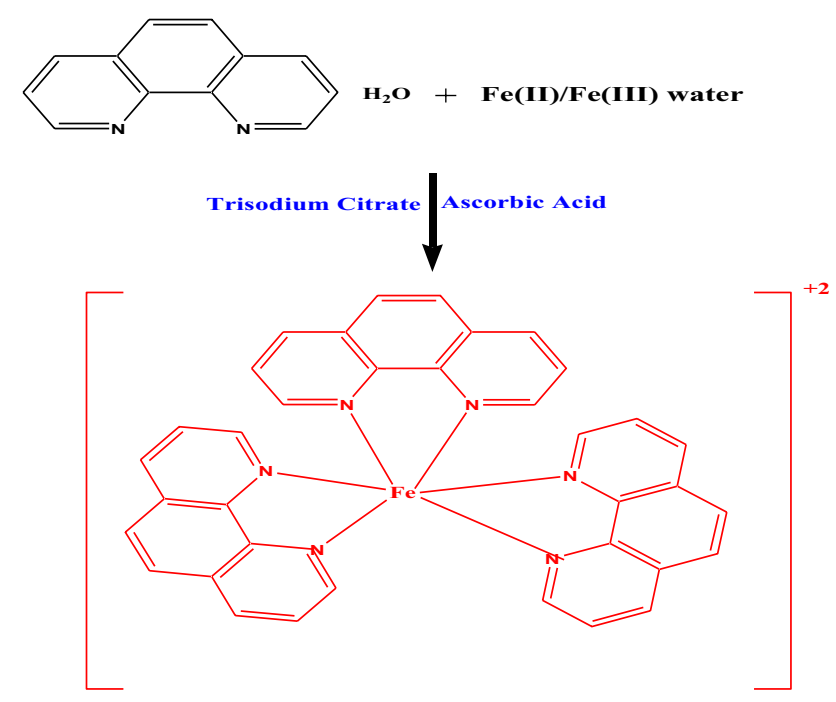

Red Colour Complex

Scheme 1 Mechanism of phenanthroline with iron(II) 
Table 1 Colour change of phenanthroline with iron presence of other metal ions and high TDS water

\begin{tabular}{|c|c|c|c|c|c|c|c|c|c|c|c|c|c|}
\hline S. no. & 1 & 2 & 3 & 4 & 5 & 6 & 7 & 8 & 9 & 10 & 11 & 12 & 13 \\
\hline $\begin{array}{l}\text { Metal ion } \\
(300 \mu \mathrm{g} / \mathrm{L}, \\
20 \mathrm{ml})\end{array}$ & $\mathrm{Ni}$ & $\mathrm{Cu}$ & Co & $\mathrm{Zn}$ & $\mathrm{Hg}$ & $\mathrm{Pb}$ & $\mathrm{Cr}$ & $\mathrm{Cd}$ & $\mathrm{Fe}$ & $\begin{array}{l}6000 \\
\text { TDS + iron } \\
\text { (II) }\end{array}$ & $\begin{array}{l}\text { Mixture metal } \\
\text { ions + iron } \\
(300 \text { ppb) }\end{array}$ & $\begin{array}{l}\text { Mixture metal } \\
\text { ions + iron (less } \\
300 \mathrm{ppb} \text { ) }\end{array}$ & Tap water \\
\hline $\begin{array}{l}\text { Colour } \\
\text { change } \\
\text { with } \\
500 \mathrm{mg} \\
\text { material }\end{array}$ & No & No & No & No & No & No & No & No & red & Red & Red & Slightly red & No \\
\hline
\end{tabular}

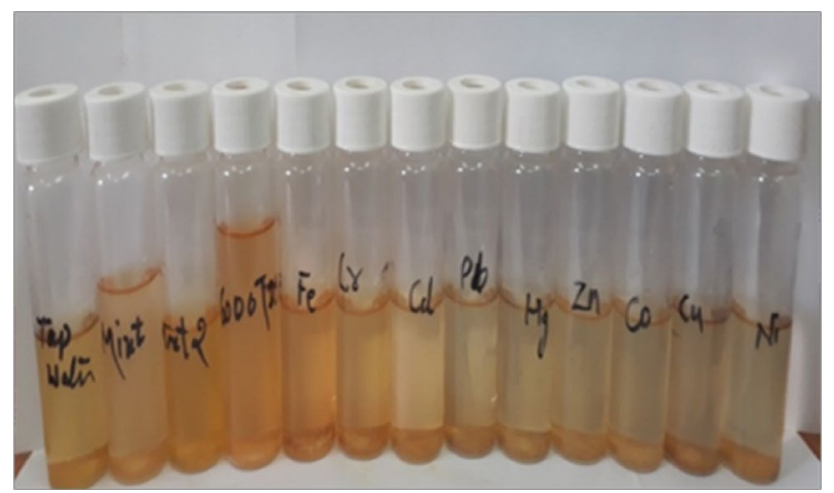

Fig. 4 Photograph of colour change of solution with different metal ions

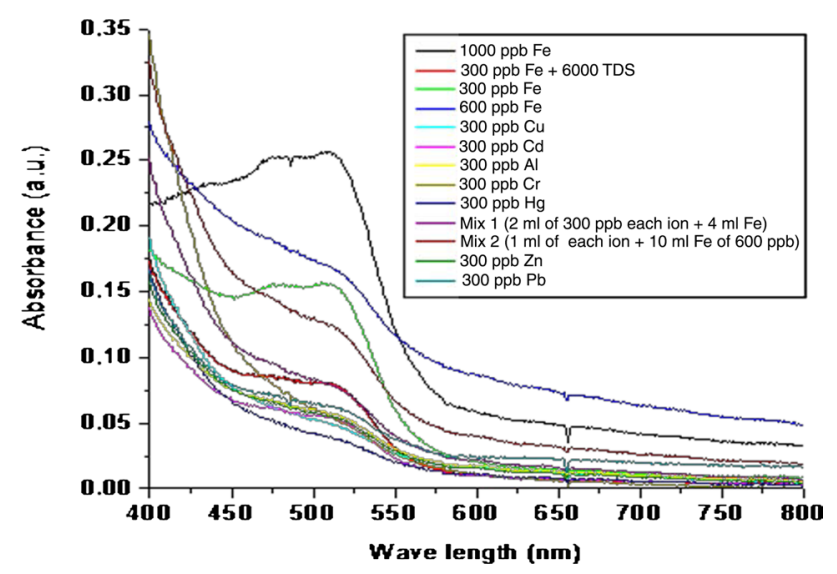

Fig. 5 UV-visible spectra of phenanthroline with iron complex with different metal ions in high TDS water

\subsubsection{Real application of the material for detection of iron}

For these studies, water samples collected were ground water. These samples were analysed for iron and TDS. These samples have iron more than $300 \mu \mathrm{g} / \mathrm{L}$ and $6000 \mathrm{Mg} / \mathrm{L}$ TDS. The material shows a significant colour change from yellow to orange red for these samples which have iron.

\section{Conclusion}

In conclusion, material was successfully prepared and optimized the ratio of reactants, viz. 1,10-phenanthroline, ascorbic acid and trisodium citrate (weight ratio 1:1:2). The prepared material was evaluated for colorimetric detection of Fe(II) ions in contaminated water. The material exhibited response towards $\mathrm{Fe}$ (II) ions, which is confirmed through colour change from yellow to orange red and UV-visible absorbance measurement. The material shows visual response with naked eye at $300 \mu \mathrm{g} / \mathrm{L}$ and response time $5 \mathrm{~min}$. UV-visible spectra of phenanthroline-Fe complex show absorbance at wavelength $510 \mathrm{~nm}$ with iron ions without interference of other metal ions, viz. $\mathrm{Ni}, \mathrm{Cu}, \mathrm{Co}, \mathrm{Zn}, \mathrm{Hg}, \mathrm{Pb}$, $\mathrm{Cd}, \mathrm{Cr}$ and high TDS water. It is a very simple and rapid detection method for ferrous ions and can be used as a potential colorimetric material for detection of iron ions in contaminated water.

Acknowledgements Authors are thankful to Dr S.R. Vadera, OS and Director, Defence Laboratory, Jodhpur, for guidance and encouragements. Authors wish to Ravindra Kumar, $\mathrm{Sc}-\mathrm{H}$, for providing technical suggestions during the preparation of the manuscript. Authors would like to thank Dr. M. S. Roy, Sc-F, and Narotam Prasad for extending UV-visible spectra analysis facility. We wish to thank all colleagues from Water Quality Management Group for their direct and indirect support.

\section{Compliance with ethical standards}

Conflict of interest The authors declare that there is no conflict of interest regarding the publication of this paper. 


\section{References}

1. Trautwein AX (2004) Bioinorganic chemistry. Wiley-VCH, Weinheim

2. Clesceri LS, Greenberg AE, Eaton AD (2012) Standard methods for the examination of water and waste water, 22nd edn. American Public Health Association/American Water Works Association/Water Environment Federation, Washington

3. Pena N, Gallego S, Dela Vigo F, Chesters SP (2012) Evaluating impact of fouling on reverse osmosis membranes performance. Desalin Water Treat 51:958-968

4. Kumar M, Adham SS, Pearce WR (2006) Investigation of seawater reverse osmosis fouling and its relationship to pretreatment type. Environ Sci Technol 40:2037-2044

5. Speth TF, Gusses AM, Summers RS (2000) Evaluation of nanofiltration pretreatments for flux loss control. Desalination 130:31-44

6. Shirazi S, Lin C, Chen D (2010) Inorganic fouling of pressuredriven membrane processes - a critical review. Desalination 250:236-248

7. Amjad Z (2010) The science and technology of industrial water treatment. CRC Press, Boca Raton

8. Armstrong MW, Gallego S, Chesters SP (2009) Cleaning clay from fouled membranes. Desalin Water Treat 10:108-114

9. Pokhrel LR, Ettore N, Jacobs ZL, Zarr A, Weir MH, Scheuerman PR, Kanel SR, Dubey B (2017) Novel carbon nanotube (CNT)-based ultrasensitive sensors for trace mercury(II) detection in water: a review. Sci Total Environ 574:1379-1388

10. Takur S, Sharma B, Verma A, Chaudhary J, Tamulevicius S, Thakur VK (2018) Recent progress in sodium alginate based sustainable hydrogels for environmental applications. J Clean Prod 198:143-159

11. Dasgupta N, Shivendu R, Chidambaram R (2017) Applications of nanotechnology in agriculture and water quality management. Environ Chem Lett 15:591-605

12. Feng L, Musto CJ, Suslick KS (2010) A simple and highly sensitive colorimetric detection method for gaseous formaldehyde. J Am Chem Soc 132:4046-4047
13. Caldwell DH, Adams R (1946) Colorimetric determination of iron in water with ophenanthroline. J Am Water Works Assoc 38:7246-7272

14. Skoog DA, West DM, Holler FJ, Crouch SR (1959) Analytical chemistry: an introduction, 7th edn, pp 547-592 (Chapters 21 and 22), Saunders College Publisher

15. Reitz LK, Obrien AS, Davis TL (1950) Evaluation of three iron methods using a factorial experiment. Anal Chem 22:1470-1473

16. Morris RL (1952) Determination of iron in water in the presence of metals. Anal Chem 24:1376-1378

17. Dima G, Popescu IV, Stihi C, Oros C, Dinu S, Manea L, Vlaicu G (2006) Fe, $\mathrm{Mn}$ and $\mathrm{Zn}$ concentrations determination from IALOMITA river by atomic absorption spectroscopy. Rom J Phys 51:667-674

18. Paus PE (1973) Determination of some heavy metals in sea water by atomic absorption spectroscopy. Anal Chem 264:118-122

19. Ferreira SLC, Queiroz AS, Assis JCR, Korn MGA, Costa ACS (1997) Determination of iron in alkaline salts by ICP-AES using 1-(2-Thiazolylazo)-p-cresol for preconcentration and separation. J Braz Chem Soc 8:621-624

20. Singh A, Kachwaha A, Malodia P, Jain SK, Khatri PK, Goswami DC, Banerjee $S$ (2008) Integration and up gradation of water testing kits developed by DL Jodhpur and DRL Tezpur. Technical report no: DRDO/DLJ/TC/DEST-2008-24

21. Kumar R, Jain SK, Verma S, Malodia P, Harwani G (2014) Feasibility study of colorimetric materials to develop indicator strips for detection of toxic metal ions. Technical report no: DRDO/DLJ/ DEST/TCR-23-2014

Publisher's Note Springer Nature remains neutral with regard to jurisdictional claims in published maps and institutional affiliations. 